\title{
Integrated Administrative Service Procedure, Infrastructure Facilities Toward Society Satisfaction of Quality Services as Variable Mediation (Study at Purwosari Subdistrict Office)
}

\section{Dyah Sawitri¹, Aprieni Eko Sulistyawati², Riezky Amalia3, and Enlik Kresnaini4}

${ }^{1}$ Faculty of Economy and Business, University of Gajayana, Malang

${ }^{2}$ Post-Graduate Program, University of Gajayana, Malang

${ }^{3}$ Accounting Major of Politeknik Negeri, Malang

${ }^{4}$ Lecturer of Faculty of Economy and Business University of Gajayana Malang

\section{Abstract}

Integrated administrative service procedure (PATEN) aims to improve the service quality and service to the community from the aspect of time and the cost of service,

Corresponding Author:

Dyah Sawitri

dyahsawitri19@yahoo.com

Received: 29 August 2018

Accepted: 18 September 2018

Published: 11 November 2018

Publishing services provided by Knowledge

(c) Dyah Sawitri et al. This article is distributed under the terms of the Creative Commons

Attribution License, which permits unrestricted use and redistribution provided that the original author and source are credited.

Selection and Peer-review under the responsibility of the ICOI-2018 Conference Committee. and improve service quality and service closer to the community. This research is conducted at Kantor Kecamatan Purwosari - Kabupaten Pasuruan. The purpose of this research is to analyze and prove that an integrated administrative service Sub procedures (PATEN) affect significantly the quality of the attendant and the satisfaction of the community; the existence of indirect influence on the procedure of integrated administrative service (PATEN) against the satisfaction of society through quality of service; and the indirect influence of infrastructure against society satisfaction through the quality of service. This research is an explanatory survey research. The population in this research is 3,250, the sample used was 97 people who use the service at Purwosari Subdistrict. Data analysis used is path analysis. Calculation of the parameters was performed using SPSS program. The result of the research are as follows: (1) There are positive and significant effects between Subdistrict Integrated administrative service procedure (Patents) toward service quality (amounting to $0.315^{*}$ ); (2) There are direct and significant effects between Integrated administrative service procedure toward society satisfaction (amounting to $\left.0.218^{\star}\right)$; (3) There are significant effects between infrastructure toward quality of service (amounting to 0.387); (4) There are significant effects between infrastructure toward society satisfaction (amounting to $0.236^{\star}$ ); (5) There are significant effects between the quality of the service toward society satisfaction (amounting to $0.492^{*}$ ); (6) There are indirect effects of administrative service procedure of subdistrict toward socift: seats sfaction through service quality (amounting to 0.155*); (7) There are indirect effects of infrastructure toward society satisfaction through service quality (amounting to o.19**) These show that the infrastructures affect positively, and significantly against the society satisfaction through service quality. The higher the work together in a way that is structured to achieve a goal of a number of speccitic service quality, which is caused by better infrastructure, the more likely it incleases 
targets that have been set. In general, organization is divided into two groups, the private sector organization and public sector organization. Public sector organizations is the organization that aims to produce a service to the community, without differentiating the status and position. Public sector organizations oriented to the public interest, which are not profit-oriented as the ultimate goal.

Respond to the dynamics of development of the Organization of local governance to good governance, which pay attention to the needs and demands of the community in the public service, he government issued Peraturan Menteri Dalam Negeri Nomor 4 Tahun 2010 Tentang Pedoman Penyelenggaraan Administrasi Terpadu Kecamaton (PATEN) on $15^{\text {th }}$ January 2010.

The regulation regarding the guidelines of the Integrated Administration of the subdistrict (Pedoman Penyelenggaraan Administrasi Terpadu Kecamatan (PATEN)) issued by the Minister of Home Affairs is to provide local government in this regard, the regent or the mayor a chance to optimize the role of subdistrict in order to build access and able to improve the infrastructure, as well as exposing services to the society in district areas or municipal areas that are geographically suitable to implement PATEN.

The scope of PATEN covers the areas of licensing and non-licensing services. The purpose of PATEN implementation is to actualize the subdistrict as the service center of the society and be the node service for integrated service agency or office in district areas or municipal area. PATEN intend to improve the quality and exposing service toward society. PATEN is a simple innovation but provide great benefits, in addition to facilitate the community to obtain service, also improve the image and government legitimation in publics' eyes.

According to Kepmen PAN No. 25 tahun 2004 concerning Public Satisfaction Index, there are 14 matters related to performance and service performed by service personnel, such as service procedure, suitability, clarity of employees, employee discipline, employee responsibilities, employee ability, service speed, service justice, employee courtesy, reasonable cost, cost certainty, schedule certainty, environmental comfort, and security of service. This research conducted to analyze the value of the variables, and their effect on the satisfaction of the community. The scope of this study is limited by service procedure, infrastructure, society satisfaction and integrated service quality of sub-district/PATEN (study at Purwosari subdistrict office, Pasuruan) 


\section{Literature Review}

Community satisfaction is a factor that determines the success of an institution. According to ([14]: 83) the definition of the Service is any action or activity which may be offered by a party to another party, which is essentially intangible and does not result in any ownership. In this case is to meet consumer needs or wants in order to achieve consumer or community satisfaction.

\section{Public Service}

\subsection{Definition of service}

Service is essentially a series of activities, therefore the service process takes place on a regular and continuous basis, encompassing the entire chain of organizational life in the community of its purpose to satisfy society. According to ([13]: 11), "service can be interpreted as a given activity to help, prepare, and take care of either in the form of goods or services from one party to another party."

According to Parasuraman, Zeithaml and Berry (1985) cited by Sopiatin (2010, pp. 40-43) there are five basic dimensions of service quality: Thus, there are five key dimensions:

1. Tangible evidence, including physical appearance, equipment, personnel, and means of communication. The tangible dimension is measured using the sense of sight to assess a service quality.

2. Reliability, that is, the dimension relates to the agency's ability to deliver its services correctly, to fulfill its promise and be reliable. Aspects to be considered in this dimension are the consistency of performance and reliability. The reliability, skills and capability of delivering prompt, accurate and satisfactory service.

3. Capacity (Responsiveness), namely Dimensions is related to the ability of employees, namely the desire of the staff and employees to help consumers and provide responsive services.

4. Assurance In this dimension, employee behavior is expected to be able to foster customers' trust in the services provided by the agency, while the Guarantees here include knowledge, skills, courtesy and credibility of staff, free from hazards, risks or doubtfulness. 
5. Empathy in the understanding of psychology is a mental state that makes a person feel himself in the other person's feelings. (Sopiatin, 2010, 41) In this dimension, it includes ease in making connections, good communication, personal attention, and understanding the needs community/customers.

\subsection{Definition of public service}

In terminology, the word service contain two meanings; the attendance of an inferior upon superior or to be useful (afrial ), 2008). Public terminology is defined as group of people. Lonsdale and Enyedi as quoted by Zauhar means something made available to whole of population and it involves things which people can not normally provide themselves, that is, must act collectively (Zauhar, 2001).

Rendering to Undang-Undang No.25 Tahun 2009 concerning Public Service is defined public service as follow: public service is the activity or series activities in order to fulfil service needs in accordance to the legislation for every citizens or residence of goods, services and/or administrative services provided by public service

\subsection{Form of public services}

In accordance to Kepmenpan N0.63/Kep/M.PAN/7/2003 concerning the general guidelines of public service delivery. Forms of service provided to the community can be divided into several types of services are:

1. Administrative Services, Services that result in various forms of official documents required by the public, such as citizenship status and ownership or control of an item and so forth.

2. Service of Goods, Services which result in various forms or types of goods used by the public, such as the provision of electric power, clean water, telephone network, and so forth.

3. Services, Services that result in a variety of services required by the public, such as the implementation of transportation, health care, the implementation of educators, as well as the implementation of other public facilities.

\subsection{Elements of public service}

There are four important elements in the public service process, those are ([6]:11): 
1. Service providers, parties that can provide a particular service to consumers, whether in the form of services and the delivery of goods or services.

2. Recipients of services, those who are referred to as consumers or customers who receive various services from service providers.

3. Type of service, which is the service that the service provider may provide to those who need the service.

4. Customer satisfaction, in providing service providers must refer to the main purpose of service, namely customer satisfaction. This is very important because the level of satisfaction that customers get is usually very closely related to the quality standards of goods and or services they enjoy.

\subsection{Integrated administrative service of subdistrict (PATEN)}

The definition of Integrated Administrative Service of subdistrict (PATEN) is public service delivery in subdistrict which its process, from the application to the publication of the document done in one place. The difference between conventional service and PATEN, as can be seen in Table 1.

The purpose and objective of PATEN is to improve the quality of service and bring the service to the community to actualize the district as a community service center and serve as a service node for one-door integrated service agency/office (PTSP) in districts/municipalities for districts that are geographically more effective and efficiently served through the sub-district. The scope of services in the field of licensing and service areas of non-licensing.

\subsection{Implementation of PATEN policy}

PATEN is conducted with the intention to actualize the sub-district as a community service center and serve as a service node for one-door integrated service agency/office (pelayanan terpadu satu pintu (PTSP)) in districts/municipalities for subdistricts that are geographically more effective and efficient in the service through sib district. The essence of a system built in integrated PATEN or integrated one-stop service is to integrate all licensing and non-licensing under the jurisdiction of the district/municipal government within an agency called a one-door integrated service agency, but the subdistrict may play the role of service knot for the agency/office One-stop integrated service or integrated administrative procedures of the subdistrict (PATEN). 
TABLE 1: The difference between Conventional Service and PATEN.

\begin{tabular}{|c|c|c|}
\hline Aspect & Conventional Service & PATEN \\
\hline \multirow[t]{2}{*}{$\begin{array}{l}\text { Participation of } \\
\text { Community }\end{array}$} & $\begin{array}{l}\text { 1. There is no community } \\
\text { participation }\end{array}$ & $\begin{array}{l}\text { 1. Community can access service } \\
\text { information. Therefore, it is easier to } \\
\text { give recommendation for service } \\
\text { improvement }\end{array}$ \\
\hline & 2. Community only & $\begin{array}{l}\text { 2. Community may file a complaint } \\
\text { when the service rendered does not } \\
\text { comply with the prescribed } \\
\text { standard }\end{array}$ \\
\hline \multirow[t]{4}{*}{$\begin{array}{l}\text { Availability of } \\
\text { Information }\end{array}$} & $\begin{array}{l}\text { 1. There are no information } \\
\text { rendering requirements, cost and } \\
\text { time; so that public will tend to pay } \\
\text { more in order to get faster service }\end{array}$ & $\begin{array}{l}\text { 1. There are information provided } \\
\text { rendering type of the service, time, } \\
\text { cost and the service procedure }\end{array}$ \\
\hline & $\begin{array}{l}\text { 2. Information is usually directly } \\
\text { delivered by the officials to the } \\
\text { residents who attend the service }\end{array}$ & $\begin{array}{l}\text { 2. There is socialization concerning } \\
\text { public service delivery. Receipt of } \\
\text { service charges can be directly } \\
\text { monitored, because payments are } \\
\text { recorded in a transparent and } \\
\text { accountable manners. }\end{array}$ \\
\hline & $\begin{array}{l}\text { 3. Head of the subdistrict find } \\
\text { difficulty to control service cost for } \\
\text { his/her staff }\end{array}$ & \multirow[t]{2}{*}{$\begin{array}{l}\text { 3. Give the certainty to the head of } \\
\text { the subdistrict in conducting public } \\
\text { service. }\end{array}$} \\
\hline & $\begin{array}{l}\text { 4. There is no database system } \\
\text { rendering the service. The head of } \\
\text { the subdistrict can be trapped with } \\
\text { accusations 'kutipan liar' }\end{array}$ & \\
\hline Database & $\begin{array}{l}\text { There is no database system } \\
\text { rendering the service. }\end{array}$ & $\begin{array}{l}\text { Comes with the service database } \\
\text { that is managed and updated } \\
\text { continuously. }\end{array}$ \\
\hline
\end{tabular}

Subdistricts that have been authorized with delegation of authority to abbreviate the bureaucratic chain. The idea of this statement is that public used to attend district area, but now public could only attend the subdistrict office.

\subsection{Infrastructure}

Infrastructure here means the ability of agencies to be able to implement or guarantee the procurement and management of adequate funds, provision, maintenance of facilities and infrastructure, as well as a good information system to support the quality of service to the community.

\subsection{The nature of community satisfaction}

Satisfaction or dissatisfaction is a person's feeling that comes from the comparison between his/her impression of the actual product performance with the expected 
product performance ([31]: 180). Further explained by Zeithmal and Bitner ([31]: 180) that consumer satisfaction is "customers of a product or service in terms of whether that product or service has met their needs an expectation."

According to Selnes (in [23]), indicators in public satisfaction are: Overall satisfaction level (overall satisfaction), Suitability of service with expectation (expectation), level of satisfaction of society during relationship with the institution (experience.

\subsection{Conceptual framework}

According to the previous theories stated, therefore the conceptual framework can be proposed in Figure 1.

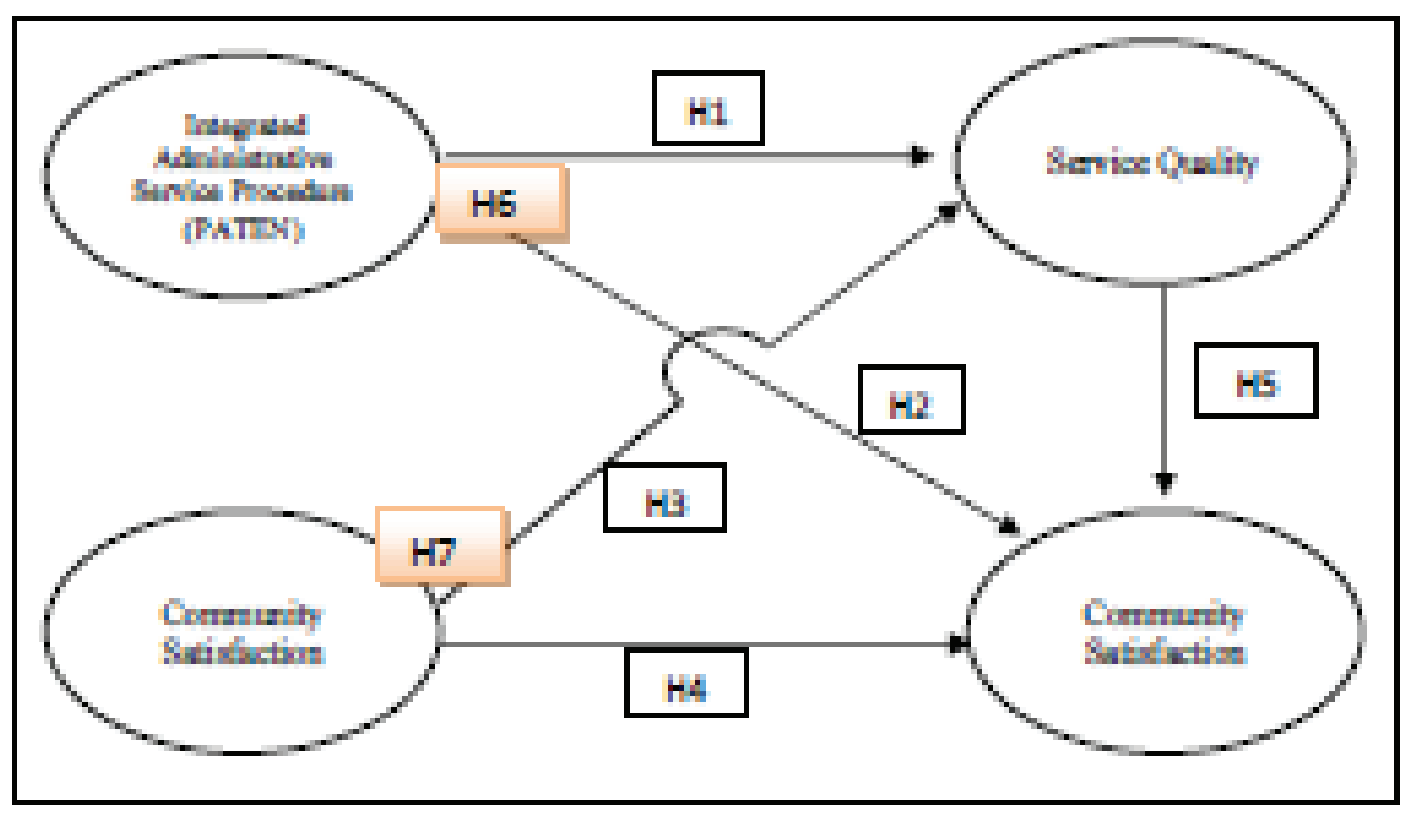

Figure 1: Conceptual framework, Integrated Administrative Service Procedure (PATEN), Infrastructure toward Community Satisfaction with Service Quality as the mediation variable. (Source: Hair (2013), processed by the researcher (2017).)

\section{Hypothesis}

The development of the hypothesis in this study is as follows:

$\mathrm{H}_{1}$ : there is a significant effect between Service procedures toward service quality

$\mathrm{H}$ 2: there is a significant effect between Service procedures toward community satisfaction

$\mathrm{H}_{3}$ : there is a significant effect between infrastructure toward service quality 
$\mathrm{H}_{4}$ : there is a significant effect between Infrastructure toward community satisfaction

H5: there is a significant effect between Service quality toward community satisfaction

H6: is there any indirect effects of Service procedure toward Community satisfaction through service quality?

$\mathrm{H}_{7}$ : is there any indirect effect of infrastructure toward community satisfaction through service quality?

\section{Research Method}

\subsection{Type of research}

This study concluded as descriptive research through survey approach. Problem solving in this research begins with literature review which include theoretical review, previous empirical studies and models relevant to the research problem. This research is designed to answer the problems that have been formulated, the purpose of this research is to test the hypothesis and to analyze the test results associated with the Procedures of Integrated Administration Services (PATEN), infrastructure toward public satisfaction with the service quality as mediation variable.

\subsection{Population and sample}

Population is a generalization area consisting of objects or subjects that have certain qualities and characteristic set by the researcher to be studied and then drawn the conclusion [35]. The population is all the customers (community) who have used the service in Purwosari Subdistrict Office of 3,250 customers/citizens.

Sampling was done with non-probability sampling technique with Purposive sampling method. Determination of number of respondents was done by determining the Slovin formula in Riduwan (2005: 65), $n=N /(1+N$. (e) 2). Based on the criteria included in the category, then obtained conclusions to involve approximately 97 respondents in this study. 


\subsection{Data collection method}

The data collection method used in this research is questionnaire, with aims to collect written information directly from respondent.

\subsection{Operational definition}

In summary the operational definition of the variables is presented in Table 2.

TABLE 2: Matrix definition of operational variable.

\begin{tabular}{|c|c|c|c|}
\hline Variable & Dimension & Indicator & Reference \\
\hline \multirow[t]{2}{*}{$\begin{array}{l}\text { Integrated } \\
\text { Administration } \\
\text { Service } \\
\text { Procedures } \\
\text { (PATEN) (X1) }\end{array}$} & $\begin{array}{l}\text { Time efficiency } \\
\left(\mathrm{X}_{1.1}\right)\end{array}$ & $\begin{array}{l}\text { 1. Faster service or more efficient time } \\
\text { (time certainty) } \\
\text { 2. Service officers working in accordance } \\
\text { with Standard Operating Procedures } \\
\text { (SOP); Integrated Administrative on } \\
\text { Service Procedure in sub district (PATEN) }\end{array}$ & $\begin{array}{l}\text { Peraturan Bupati } \\
\text { Pasuruan No. } 29 \\
\text { Tahun 2015, Pasal } \\
\text { (1) ayat: } 5 \text { dan } 8 \\
\text { Pasal } 2 \text { dan Pasal } \\
3\end{array}$ \\
\hline & $\begin{array}{l}\text { Policy } \\
\text { implementation } \\
\left(\mathrm{X}_{1.2}\right)\end{array}$ & $\begin{array}{l}\text { 1. Convenience of signing affairs related } \\
\text { to administrative of population for the } \\
\text { continuity of service toward public } \\
\text { 2. The signing of the file may represent } \\
\text { officials in accordance with the hierarchy } \\
\text { in order to serve the community more } \\
\text { efficiently and effectively } \\
\text { 3. Implementation of One Door Service } \\
\text { for all services in subdistricts, both } \\
\text { licensing and non-licensing services to } \\
\text { facilitate services to the community } \\
\text { 4. Accountability of PATEN execution } \\
\text { process that can be can be accounted for } \\
\text { in accordance with laws and regulations }\end{array}$ & \\
\hline \multirow[t]{2}{*}{$\begin{array}{l}\text { Infrastructure } \\
\left(X_{2}\right)\end{array}$} & $\begin{array}{l}\text { Supporting } \\
\text { facilities of service } \\
\text { in the form of } \\
\text { fixed assets }\left(\mathrm{X}_{2.1}\right)\end{array}$ & $\begin{array}{l}\text { 1. Has the service room met the comfort } \\
\text { criteria? } \\
\text { 2. How is the cleanliness and neatness } \\
\text { the place of service? } \\
\text { 3. There are wide parking area, } \\
\text { availability of physical facilities such as: } \\
\text { waiting room service, parking, places of } \\
\text { worship (Mosque), Toilets, etc. }\end{array}$ & Bafadal (2008:2) \\
\hline & $\begin{array}{l}\text { Supporting service } \\
\text { facilities in the } \\
\text { form of disposable } \\
\text { goods }\left(\mathrm{X}_{2.2}\right)\end{array}$ & $\begin{array}{l}\text { 1. How is the availability of disposable } \\
\text { goods to support public service? } \\
\text { 2. How is the availability of blank forms } \\
\text { to support the service? }\end{array}$ & \\
\hline \multirow[t]{2}{*}{$\begin{array}{l}\text { Public Satisfaction } \\
\text { (Y) }\end{array}$} & $\begin{array}{l}\text { Overall } \\
\text { Satisfaction Level } \\
\left(Y_{1.1}\right)\end{array}$ & $\begin{array}{l}\text { 1. The implementation of simplicity in } \\
\text { service process } \\
\text { 2. The implementation of service clarity }\end{array}$ & $\begin{array}{l}\text { (Salnes dalam } \\
\text { Rayi Endah, 2008) }\end{array}$ \\
\hline & $\begin{array}{l}\text { Suitability of } \\
\text { service with } \\
\text { community } \\
\text { expectations } \\
\text { (Expectation) }\left(Y_{1.2}\right)\end{array}$ & $\begin{array}{l}\text { 1. There is a certainty result of the } \\
\text { service } \\
\text { 2. Implementation of product service } \\
\text { accuracy }\end{array}$ & \\
\hline
\end{tabular}




\begin{tabular}{|c|c|c|c|}
\hline \multirow[t]{2}{*}{ Variable } & Dimension & Indicator & Reference \\
\hline & $\begin{array}{l}\text { Public satisfaction } \\
\text { level during the } \\
\text { process with the } \\
\text { instance } \\
\text { (Experience) }\left(Y_{1.3}\right)\end{array}$ & $\begin{array}{l}\text { 1. There is safety during the service } \\
\text { 2. Easy access of services } \\
\text { 3. Public comfort during the service }\end{array}$ & \\
\hline \multirow[t]{5}{*}{$\begin{array}{l}\text { Service Quality } \\
\text { (Z) }\end{array}$} & Relatability $\left(Z_{1}\right)$ & $\begin{array}{l}\text { 1. Hospitality of the officers while } \\
\text { serving community } \\
\text { 2. Service officers behavior toward } \\
\text { customer (citizens) is same and no } \\
\text { discrimination (equal rights) }\end{array}$ & $\begin{array}{l}\text { Parasuraman, } \\
\text { Zeithaml dan } \\
\text { Berry (1985) as } \\
\text { quoted by } \\
\text { Sopiatin (2010, } \\
\text { pg. 40-43) }\end{array}$ \\
\hline & $\begin{array}{l}\text { Responsiveness } \\
\left(Z_{2}\right)\end{array}$ & $\begin{array}{l}\text { 1. The availability of easy access and } \\
\text { services information such as service } \\
\text { procedure board } \\
\text { 2. Service officers provide special } \\
\text { trainings (individuals) on certain issued } \\
\text { such ass disabled, elderly, and pregnant } \\
\text { women } \\
\text { 3. The availability of facility for complaint } \\
\text { delivery such as complaint box }\end{array}$ & \\
\hline & Assurance $\left(Z_{3}\right)$ & $\begin{array}{l}\text { 1. The assurance of certainty that the } \\
\text { service is resolved } \\
\text { 2. Service officers provide services with } \\
\text { honesty and firmness }\end{array}$ & \\
\hline & Empathy $\left(Z_{4}\right)$ & $\begin{array}{l}\text { 1. Service officers are polite and friendly } \\
\text { 2. Service officers provide information to } \\
\text { customers (citizens) with clear and } \\
\text { understandable language } \\
\text { 3. Service officers provide services with } \\
\text { sincerity and full sense of responsibility }\end{array}$ & \\
\hline & Tangible $\left(Z_{5}\right)$ & $\begin{array}{l}\text { 1. Implementation of electronic systems } \\
\text { for electronic ID record, or other public } \\
\text { services } \\
\text { 2. Officers' appearance and uniform is } \\
\text { neat and clean }\end{array}$ & \\
\hline
\end{tabular}

Source: Peraturan Bupati Pasuruan no.29 (2015); Bafadal (2008); Salnes dalam Rayi Endah (2008); Parasuraman, Zeithaml dan Berry (1985) as quoted by Sopiatin (2010); processed by the researcher (2017)

\subsection{Scale of measurement}

Variable measurement of this research is used Likert scale, with scores on this scale starting from 1 to 5, with scores: Very Good (score 5), Good (score 4), Fair (score 3), Not Good (score 2), Very Not Good (score 1).

\section{Data Analysis Method}




\subsection{Descriptive analysis}

The analysis method in this research used descriptive analysis to describe the object of the research, descriptive analysis is used only to process and present the data without taking any decisions in this research.

\subsection{Path analysis}

Path analysis is used to analyze the relationship pattern between variable with the purpose to find the direct and indirect effect between the set of independent variables toward dependent variable. The path analysis model discussed is the pattern of causal relationships. Therefore, the formulation of research problem in the framework of path analysis only revolves around whether the independent variables $\left(X_{1}, X_{2}, \ldots, X_{k}\right)$ affect the variable $Y$, or how much direct causal influence, causal indirect, total causal or simultaneous set of independent variables $\left(X_{1}, X_{2}, \ldots, X_{k}\right)$ affect the variables $Y$. (Riduwan and Engkos Kuncoro, 2008), and (Hair, 2013).

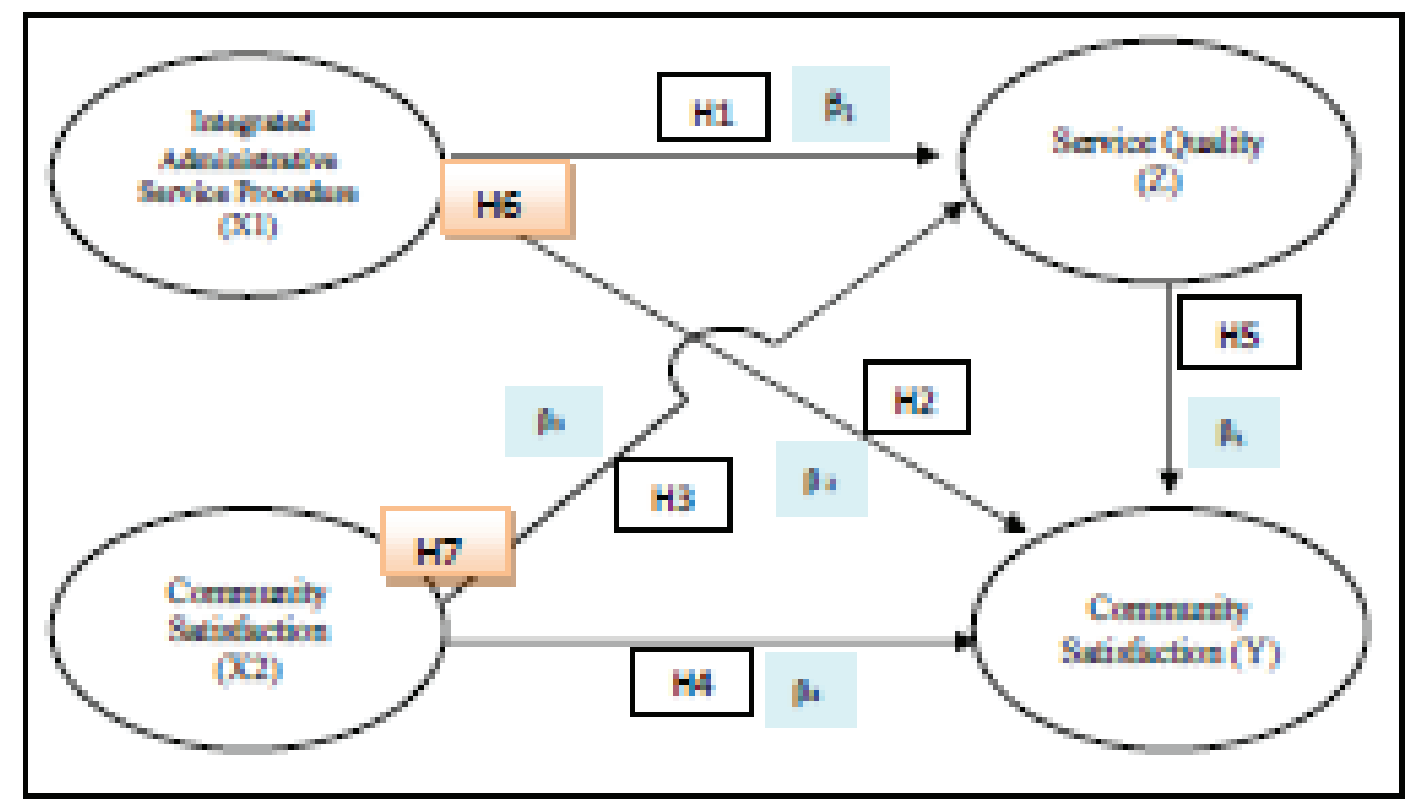

Figure 2: Diagram Path Model. (Source: Hair (2013); processed by researcher (2017).)

Equation in path analysis:

1. $Z=\beta_{1} X_{1}+\beta_{2} X_{2}+\epsilon_{1}$

2. $Y=\beta_{1} X_{1}+\beta_{2} X_{2}+\beta_{3} Z+\epsilon_{2}$ 


\subsection{Hypothesis testing}

The hypothesis testing is done to test the effect, partially used the $t$-test. Independent variable is stated to have partially significant effect if the significant value of $t$ smaller than the alpha. The measure of significance of hypothetical support can be used for comparison of $T$-Table and $T$-statistic values. If $T$-statistic is higher than $T$-table values, it indicates that the hypothesis is supported or accepted. In this study the confidence level is 95\% (alpha 95\%).

\section{Research Result Analysis and Discussion}

\subsection{Characteristic of respondents}

The characteristic of respondents in this research is based on gender, education and age (Tables 3-5).

\subsubsection{Gender}

The results of descriptive statistical analysis for respondent's characteristic based on the gender is shown as follows:

TABLE 3: Characteristic based on gender.

\begin{tabular}{l|c|c|c|}
\hline No. & Gender & Frequency & Presentation \\
\hline 1 & Men & 37 & $38 \%$ \\
\hline 2 & Women & 60 & $62 \%$ \\
\hline 3 & Total & 97 & $100 \%$ \\
\hline
\end{tabular}

Based on Table 3, it can be concluded that most of the community who became respondents is men with the amount of $38 \%$ and women with the amount of $62 \%$.

\subsubsection{Education}

The results of descriptive statistical analysis for respondent characteristic based on education is shown as follows:

Based on Table 4, it is shown that the most education earned by respondents with the percentage of $31 \%$ are Senior High School. Meanwhile, $26 \%$ of respondents are 
TABLE 4: Characteristic based on education.

\begin{tabular}{l|c|c|c|}
\hline No. & Education & Frequency & Presentation \\
\hline 1 & No School & 8 & $8 \%$ \\
\hline 2 & Elementary School & 10 & $10 \%$ \\
\hline 3 & Junior High School & 22 & $23 \%$ \\
\hline 4 & Senior High School & 30 & $31 \%$ \\
\hline 5 & Undergraduate & 25 & $26 \%$ \\
\hline 6 & Master & 2 & $2 \%$ \\
\hline & Total & 97 & $100 \%$ \\
\hline
\end{tabular}

college graduates (undergraduate), $26 \%$ of respondents are junior high school graduates, $10 \%$ of respondents are elementary school graduates and $8 \%$ of respondents are not earned education and $2 \%$ of the respondents are master graduates.

\subsubsection{Ages}

The results of descriptive statistical analysis for respondent characteristic based on ages is shown in Table 5.

TABLE 5: Characteristic based on ages.

\begin{tabular}{|l|c|c|c|}
\hline No. & Age Range & Frequency & Presentation \\
\hline 1 & $\leq 20$ years old & 7 & $7 \%$ \\
\hline 2 & 21 s/d 30 years old & 15 & $15 \%$ \\
\hline 3 & 31 s/d 40 years old & 40 & $41 \%$ \\
\hline 5 & 41 s/d 50 years old & 25 & $26 \%$ \\
\hline 4 & $\geq 50$ years old & 10 & $10 \%$ \\
\hline & Total & 97 & $100 \%$ \\
\hline
\end{tabular}

As can be seen in Table 5, it can be concluded that most of the customers that became respondents are on the age range of 31-40 years with the amount of people of respondents with the parentage of $41 \%$. Then, followed by age range $41-50$ years old with the percentage of $26 \%$, then with the age range $21-30$ years old with the percentage of $15 \%$ respondents, the next is $10 \%$ of respondents are in the age range more than 50 years old and the last is $7 \%$ of respondents are less than 20 years old. 


\subsection{Validity testing result and reliability}

This testing is intended to measure the level of accuracy and reliability of the data collection tools.

\subsection{Validity testing result}

Instrument validity testing is done by correlating each item score with total score using Pearson Correlation technique (Product moment). The result of the validity test are presented on Table 6.

\subsection{Reliability testing result}

Instrument Reliability testing of research is known that all values of Cronbach's Alpha $>0.6$, the complete reliability test results are presented in Table 7.

\section{Discussion}

\subsection{Data analysis result}

The hypothesis testing is done to answer formulation of the problem that include partial hypothesis testing. Hypothesis testing related with the direct and indirect effect that shown on Table 8 as follows.

Based on Table 8, it can be indicated that:

1. The coefficient of direct effect of administrative procedures of subdistrict administration on service quality is 0.315 *. This indicates that the integrated administrative service procedure of the subdistrict has a positive and significant impact on service quality. Thus, the better the procedures of the integrated administrative services in subdistrict, then it tends to improve the quality of service.

2. The coefficient of direct effect of the administrative procedures of the integrated administration of subdistrict toward public satisfaction of 0.218 *. It shows that the integrated administrative service procedure of the subdistrict has a positive and significant impact on the satisfaction of the community. Thus the better the procedure of the integrated administrative services of the subdistrict the more likely it increase the satisfaction of the community 
TABLE 6: Validity testing analysis result.

\begin{tabular}{|c|c|c|c|c|}
\hline Variable & Item & $\begin{array}{c}\text { Validity } \\
\text { Coefficient (sig t) }\end{array}$ & $\alpha$ & Explanation \\
\hline \multirow{6}{*}{$\begin{array}{l}\text { Subdistrict Integrated } \\
\text { Administration Service } \\
\text { Procedures }\end{array}$} & $X 1.1$ & 0.721 & 0.05 & Valid \\
\hline & $X_{1.2}$ & 0.734 & 0.05 & Valid \\
\hline & $X_{1.3}$ & 0.688 & 0.05 & Valid \\
\hline & $X 1.4$ & 0.732 & 0.05 & Valid \\
\hline & $X 1.5$ & 0.598 & 0.05 & Valid \\
\hline & $X_{1.6}$ & 0.719 & 0.05 & Valid \\
\hline \multirow[t]{5}{*}{ Infrastructure } & $X_{2.1}$ & 0.746 & 0.05 & Valid \\
\hline & $X 2.2$ & 0.611 & 0.05 & Valid \\
\hline & $X 2.3$ & 0.789 & 0.05 & Valid \\
\hline & $X 2.4$ & 0.54 & 0.05 & Valid \\
\hline & $X 2.5$ & 0.692 & 0.05 & Valid \\
\hline \multirow[t]{7}{*}{ Community Satisfaction } & $Y_{1}$ & 0.754 & 0.05 & Valid \\
\hline & $Y_{2}$ & 0.81 & 0.05 & Valid \\
\hline & $Y_{3}$ & 0.811 & 0.05 & Valid \\
\hline & $Y_{4}$ & 0.703 & 0.05 & Valid \\
\hline & $Y_{5}$ & 0.627 & 0.05 & Valid \\
\hline & Y6 & 0.696 & 0.05 & Valid \\
\hline & $Y_{7}$ & 0.748 & 0.05 & Valid \\
\hline \multirow[t]{12}{*}{ Service Quality } & $\mathrm{Z} 1$ & 0.559 & 0.05 & Valid \\
\hline & $\mathrm{Zz}$ & 0.748 & 0.05 & Valid \\
\hline & $Z_{3}$ & 0.693 & 0.05 & Valid \\
\hline & $Z_{4}$ & 0.75 & 0.05 & Valid \\
\hline & $\mathrm{Z}_{5}$ & 0.562 & 0.05 & Valid \\
\hline & Z6 & 0.628 & 0.05 & Valid \\
\hline & $\mathrm{Z}_{7}$ & 0.788 & 0.05 & Valid \\
\hline & Z8 & 0.602 & 0.05 & Valid \\
\hline & Z9 & 0.611 & 0.05 & Valid \\
\hline & $\mathrm{Z}_{10}$ & 0.731 & 0.05 & Valid \\
\hline & Z11 & 0.541 & 0.05 & Valid \\
\hline & $Z_{12}$ & 0.38 & 0.05 & Valid \\
\hline
\end{tabular}

3. The coefficient of the direct effect of infrastructure toward service quality with the amount of $0.236^{*}$. It indicates that the infrastructure has a positive and significant effect on service quality. Thus the better the infrastructure is likely to improve the quality of service. 
TABle 7: Reliability Testing Analysis Result.

Dimension
Subdistrict Integrated
Administration Service
Procedures
Infrastructure
Community Satisfaction
Service Quality

Service Quality

\begin{tabular}{|c|}
\hline $\begin{array}{c}\text { Reliability } \\
\text { Coefficient }\end{array}$ \\
\hline 0.778 \\
\hline 0.709 \\
\hline 0.857 \\
\hline 0.864 \\
\hline
\end{tabular}

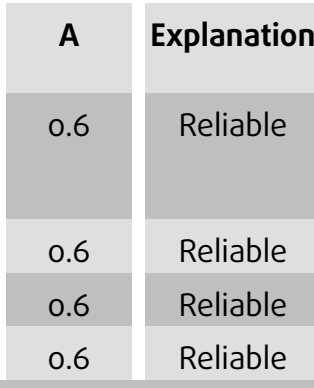

Source: Primary Data, processed in 2017.

TABLE 8: Direct and indirect effect.

Exogenous
Integrated Service
Administrative Procedure
in Subdistrict
Infrastructure
Integrated Service
Administrative Procedure
in Subdistrict
Infrastructure
Service Quality
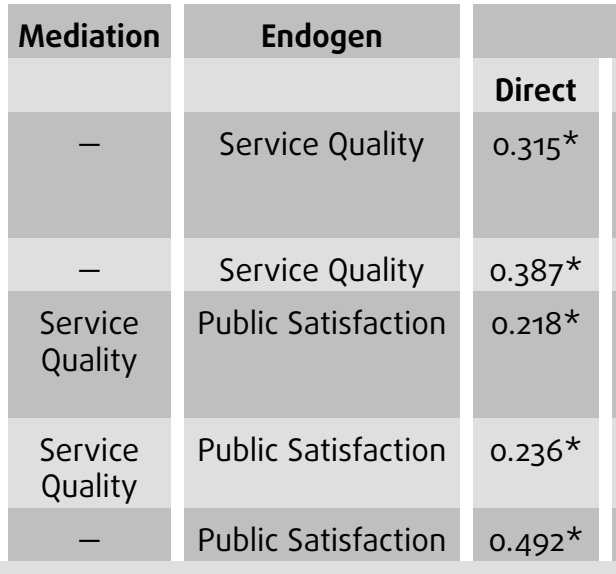

\section{Coefficient} Indirect

Total

$-$

0.315

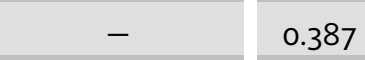

$0.155^{*}(0.315 x$

$0.492)$

0.373

$0.190 *(0.387 x$

$0.492)$

0.426

$-$

0.492

Note: * (significance).

Source: Primary data processed by researcher in 2017.

4. The coefficient of the direct effect of infrastructure toward public satisfaction (X2) of $0.236^{*}$. It signifies that that the infrastructure has a positive and significant effect on public satisfaction. Therefore, the better the infrastructure, is likely to increase public satisfaction.

\section{The coefficient of the direct effect of service quality toward public satisfaction} of $0.492^{*}$. It implies that the quality of the service has a positive and significant effect on public satisfaction. Hence, the higher the service quality then tend to increase public satisfaction.

6. The coefficient of the indirect effect of Integrated service Administrative Procedure in Subdistrict toward public satisfaction through service quality with the amount of $0.155^{\star}$. It shows that the integrated administrative procedure of the subdistrict has a positive and significant effect on public satisfaction through service quality. So, the higher the quality of services caused by the better integrated administrative procedures of subdistrict is likely to increase public satisfaction. 
7. The coefficient of the indirect effect of infrastructure toward public satisfaction through service quality of $0.190 *$. It signifies that the infrastructure has a positive and significant effect on public satisfaction. Therefore, the higher the service quality caused by the better the infrastructure is likely to increase public satisfaction.

\subsection{Partial hypothesis testing}

Partial hypothesis testing is used to test the presence of the effect of exogenous variables partially toward endogen variable. Criteria of the testing stated that if the probability value <level of significant (alpha $=\alpha$ ) $>$; it indicates that there are effect on partially exogenous variables toward endogen variables. The hypothesis testing can be known through the table as follows.

TABLE 9: Hypothesis testing.

\begin{tabular}{|c|c|c|c|c|}
\hline Exogenous & Endogen & Coefficient & T statistics & Prob/sig. \\
\hline $\begin{array}{l}\text { Integrated Service } \\
\text { Administrative Procedure in } \\
\text { Subdistrict }\end{array}$ & Service Quality & 0.315 & 2.994 & 0.003 \\
\hline Infrastructure & Service Quality & 0.387 & 3.684 & 0.000 \\
\hline $\begin{array}{l}\text { Integrated Service } \\
\text { Administrative Procedure in } \\
\text { Subdistrict }\end{array}$ & Public Satisfaction & 0.218 & 2.658 & 0.009 \\
\hline Infrastructure & Public Satisfaction & 0.236 & 2.814 & 0.005 \\
\hline Service Quality & Public Satisfaction & 0.492 & 6.491 & 0.000 \\
\hline
\end{tabular}

The influence of integrated service administrative procedure of subdistrict toward service quality resulted in in a statistic $T$-value of 2,994 with probability/sig of 0.003 . The testing results shows that the probability is less than/< alpha $(5 \%)$. This indicates that there is significant effect of integrated service administrative procedure of subdistrict (PATEN) toward service quality.

The effect of infrastructure toward service quality with the $T$-statistics value of 3.684 with the probability of 0.000 . The testing result shows that the probability is less than/<alpha (5\%). This means that there is significant effect of infrastructure toward service quality.

The effect of integrated service administrative procedure in subdistrict (PATEN) toward public satisfaction gained the value of $T$-statistics of 2.658 with the probability of 0.009 . The testing result indicates that the probability is less than or/< alpha 
(5\%). This means that there is significant effect of integrated service administrative procedure in subdistrict toward public satisfaction.

The effect of infrastructure toward public satisfaction earned the $T$-statistics value of 2.184 with the probability of 0.009 . This testing result indicates that the probability is less than alpha ( $5 \%)$. This is shows that there is significant effect toward public satisfaction.

The effect of the quality service toward public satisfaction gained the $T$-statistics value of 6.491 with the probability of 0.000 . The testing result shows that the probability is less than alpha ( $5 \%)$. It means that there is direct significance effect of service quality toward public satisfaction.

Furthermore, the effect of integrated service administrative procedure in subdistrict (PATEN) and infrastructure toward public satisfaction through service quality indicates that there is significant effect of integrated service administrative procedure in subdistrict (PATEN), infrastructure toward service quality and there is significant effect of service quality toward public satisfaction. Since both paths are significant, it can be stated that there is a significant effect of integrated subdistrict administrative service procedures and infrastructure on public satisfaction through service quality. Thus the service quality is able to mediate the effect of integrated subdistrict administrative service procedures and infrastructures on public satisfaction.

The conversion of the path diagram into the measurement model is intended to convert the diagram model into an empiric based data-based model used to determine the effect of exogenous variables on endogenous variables directly or indirectly.

Empirical model gained written as follows:

Model 1: $Z=0.315 X_{1}+0.387 X_{2}$

Model 2: $Y=0.218 X_{1}+0.236 X_{2}+0.492 Z$

\subsection{Dominant effect}

Exogenous variable that has the most effect toward endogen variables can be known from the highest total effect. Variable which has the greatest total effect toward service quality is infrastructure with the total effect of 0.387 . Therefore, infrastructure is the most influential variable or has the most dominant effect toward service quality.

Variables which has the greatest total effect toward public satisfaction is service quality with the total effect of 0.492 . Hence, service quality is the most influential variable or has the most dominant effect toward public satisfaction. 


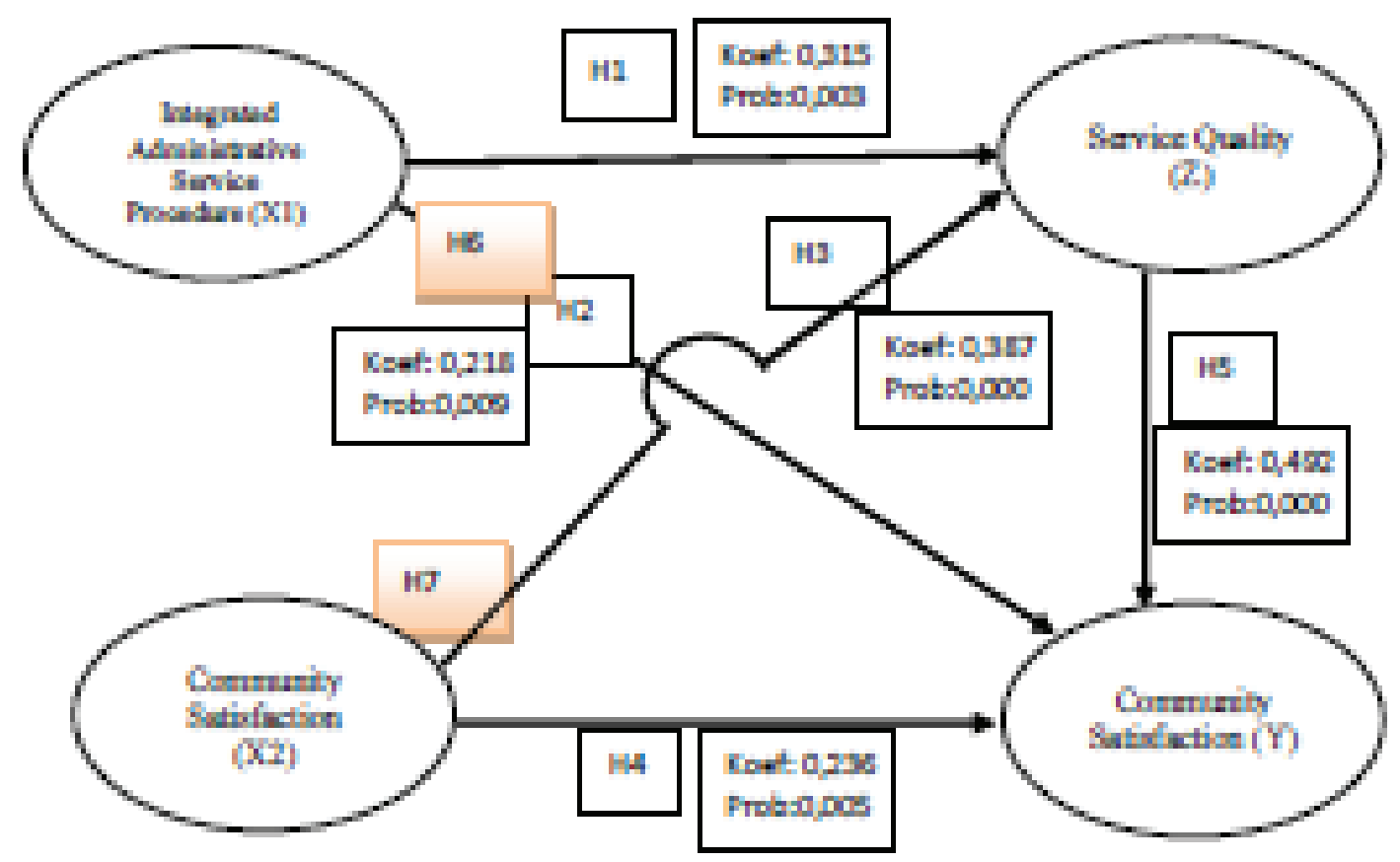

Figure 3: Model construction. (Source: Hair (2013); primary data processed by researcher in 2017.)

\section{Conclusion and Recommendation}

Based on the research result and the discussion as stated on the previous chapter, it can be drawn conclusions and suggestions as follows:

\subsection{Conclusion}

1. There is positive and significant effect between procedure of integrated administrative service (PATEN) toward service quality. This is shown that the better the subdistrict administrative service procedure, the more likely it improve the service quality.

2. There is direct and significant between integrated administrative service (PATEN) toward community satisfaction. Therefore the better the procedure of subdistrict integrated administrative service (PATEN), the more likely it increase society satisfaction.

3. There is significant effect between infrastructure toward service quality at Purwosari subdistrict office. This indicates that the better the infrastructure will tend to improve service quality 
4. There is significant effect between infrastructure toward public satisfaction on Purwosari subdistrict office. Hence, the better the infrastructure will tend to increase public satisfaction

5. There is significant effect between service quality toward public satisfaction at Purwosari subdistrict office. This indicates that the higher the service quality, is likely to increase public satisfaction

6. There is an indirect effect of integrated subdistrict administrative service procedures on community satisfaction through service quality. Thus, the higher the quality of services caused by the better administrative procedures of the subdistrict administration is likely to increase public satisfaction

7. There is an indirect effect of infrastructure on public satisfaction through service quality. This indicates that the higher the service quality caused by the better the infrastructure is likely to increase public satisfaction.

\subsection{Recommendation and implications}

Based on the study result, there are few recommendations are proposed as follows:

1. Head Office of Purwosari Subdistrict, always need to improve the Quality of Service to the community, especially related to the fulfillment of integrated administrative service procedures (PATEN), the infrastructure owned in order to increase community's satisfaction. facilities owned to increase community satisfaction. This can be done by providing clarity of procedures and the speed and accuracy of integrated administrative service procedures (PATEN) to the community, especially to improve professionals in carrying out their duties and functions. This is in an effort to help the Purwosari District provide the best service to the community

2. Infrastructure facilities in Purwosari District Office also need to be improved to increase the satisfaction of the community, it is necessary to increase information to the public, especially electronic information systems that can be accessed by the public in a timely and rapid manner to improve the quality of service to the community satisfaction

3. Other researcher need to conduct further research related to Integrated Service Administration Procedure (PATEN), Infrastructure Facility to Satisfaction of Society with Quality of Service as Variable Mediation in more depth. 


\section{References}

[1] Abdillah, W. and Jogiyanto, H. M. (2009). Konsep Dan Aplikasi PLS (Partial Least Square) Untuk Penelitian Empiris. Yogyakarta: Badan Penerbit Fakultas Ekonomi Dan Bisnis UGM.

[2] Ancok, D. (1997). Teknik Penyusunan Skala Pengukuran. Pusat Penelitian Kependudukan. Yogyakarta: Universitas Gajah Mada.

[3] Arikunto, S. (2006). Prosedur Penelitian Suatu Pendekatan Praktik (Ed Revisi VI). Jakarta: Penerbit PT Rineka Cipta.

[4] Armando, G. D. (2013). Implementasi Kebijakan Pelayanan Administrasi Pelayanan Terpadu Kecamatan (PATEN).

[5] Bafdal, N. (2011). dalam Kirom, M. (2014). Sistem Informasi Geografis Pemetaan Suara Pemilu Kada Berbasis Open Source di Kabupaten Jombang. Jurnal Ilmiah Edutic Universitos Pesantren Tinggi Darul Ulum. Jombang.

[6] Barata, A. A. (2004). Dasar - Dasar Pelayanan Prima. Jakarta : PT Elex Media Komputindo.

[7] Bateson dalam arisman. Retrieved from http//www.Kumham.Jakarta.info

[8] Dwi, R. A. (2016). Implementasi Kebijakan Pelayanan Administrasi Terpadu Kecamatan (PATEN) Di Kecamatan Pandak Kabupaten Bantul.

[9] Tjiptono, F. (2004). Manajemen Jasa. Yogyakarta: Andi Offset.

[10] Tjiptono, F. and Chandra, G. (2005). Service, Quality \& Satisfoction. Yogyakarta: Andi Offset.

[11] Fitra, N. C. (2016). Pelayanan Administrasi Terpadu Kecamatan di Kecamatan Kokap Kabupaten Kulon Progo.

[12] Ghozali, I. (2013). Aplikasi analisis multiviriate dengan program SPSS Edisi ketujuh. Semarang: Badan Penerbit Universitas Diponegoro.

[13] Hardiansyah. (2011). Kualitas Pelayanan Publik. Yogyakarta: Gava Media.

[14] Kotler, P. (2007). Manajemen Pemasaran, Jilid 2 (Edisi 12). New Jersey: PT. Indeks.

[15] Rifa'l, M. (2015). District Integrated Administrative Service (Paten) Implementation Analysis in Leles District of Garut Regency.

[16] Nurgiantoro, B. (2010). Pengujian Validitos dan Reabilitas Instrumen Penelition. Yogyakarta: Gadjah Mada University.

[17] Nurkaenti. (2015). Pengaruh pelayanan Administrasi Terpadu terhadap tingkat kepuasan Masyarakat di Kabupaten Brebes. 
[18] Parasuraman, A. A., Zeithaml, V., and Berry, L. (1995). A conceptual model of service quality and its implications for future research. Journal of Marketing, vol. 49 (fall).

[19] Parasuraman and Tjiptono, F. (1996). A conceptual model of service quality and its implications for future research.

[20] Peraturan Bupati Pasuruan Nomor 29. (2015). Tentang Pelayanan Administrasi Terpadu Kecamatan Kabupaten Pasuruanah Rosyidi (2007) Reformasi Administrasi Sub Nasional.

[21] Pravita, S. (2016). Pelayanan Administrasi Terpadu Kecamatan (Paten) Study kasus kantor Kecamatan Tanjung Pinang Kota Tanjung Pinang.

[22] Al Rahman, P. (2016). Implementasi Sistem Pelayanan Terpadu (PATEN) Di Kecamatan Lumbis Induk Kabupaten Nunukan.

[23] Rayi, E. (2008). Analisis Kualitas Layanan, Kualitas Produk, dan Harga Terhadap Kepuasan Pelanggan, Skripsi, Universitas Diponegoro.

[24] Republik Indonesia. (2003). Keputusan Menteri Pendayagunaan Aparatur Negara Nomor 63 Tahun 2003 tentang Pedoman Pelayanan Publik. Jakarta: Sekretariat Negara.

[25] Republik Indonesia. (2004). Keputusan Menteri Pendayagunaan Aparatur Negaro Nomor 25 Tahun, 2004 tentang Indeks Kepuasan Masyarakat. Jakarta: Sekretariat Negara.

[26] Republik Indonesia. (2004). Undang - Undang Nomor 32 Tahun 2004 tentang Pemerintahan Daerah. Jakarta: Sekretariat Negara.

[27] Republik Indonesia. (2010). Keputusan Menteri Pendayagunaan Dalam Negeri Nomor 4 Tahun 2010 tentang Pedoman Penyelenggaraan Administrasi Terpadu Kecamaton (Paten). Jakarta.

[28] Riduwan. (2005). Skala Pengukuran Variabel-Variabel Penelitian. Bandung: Alfabeta.

[29] Riduwan. (2007). Metode Penelitian untuk Tesis. Bandung: Alfabeta.

[30] Rozy Alfrial, J. (2009). Kualitas Pelayanan Publik Kecamatan setelah perubahan kependudukan dan fungsi Camat sebagai perangkat daerah.

[31] Sangadji, E. M. and Sopiah. (2013). Prilaku Konsumen: Pendekatan Praktis Disertai: Himpunan Jurnal Penelition. Yogyakarta: Penerbit Andi.

[32] Schumacher, R. E. and Lomax, R. G. (1996). A Beginners Guide to Structural Equation Modeling. Hilsdale.

[33] Sekaran, U. (2011). Research Methods for Business (Edisi I and 2). Jakarta: Salemba Empat.

[34] Singarimbun, M. and Sofian, E. (2009). Metode Penelition Survai. Jakarta: LP3ES. 
[35] Sugiyono. (2012). Metode Penelitian Kuantitatif Kualitatif dan R\&D. Bandung: Alfabeta.

[36] Utomo, S. D. (2010). Kebijakan Pelayanan Administrasi Terpadu Kecamatan (PATEN): Inovasi Manajemen Pelayanan di Kecamatan. Direktorat Jenderal Pemerintahan Umum Kementerian Dalam Negeri Republik Indonesia.

[37] Widodo, J. (2001). Good Governance Telaah Dari Dimensi Akuntabilitas, Kontrol Birokrasi Pada Era Desentralisasi Dan Otonomi Daerah. Surabaya: Insan Cendekia.

[38] Wijyanto, S. H. (2008). Structural Equation Modeling dengan LISREL 8.8. Yogyakarta: Graha Ilmu. 